\title{
Russia's Turn to the East: Domestic Policymaking and Regional Cooperation
}

\author{
Helge Blakkisrud \& Elena Wilson Rowe (red.) \\ Warwick: Palgrave Macmillan 2018 \\ 167 sider. ISBN 978331969785
}
Omtalt av Tom Røseth [Ph.d, førsteamanuensis, Forsvarets høgskole, tom.roseth@ fhs.mil.no]

Forholdet mellom Russland og Kina er blant samtidens viktigste temaer for å studere utviklingen i global sikkerhetspolitikk. Deres styrkede samarbeid over de siste to tiårene er sett på som en hovedutfordring til den USA-dominerte vestlige verdensordenen. Men hvor tett er egentlig samarbeidet, hvor betydelig er russisk politikkendring henimot Asia, og vil Kina og Russland etablere en militær forsvarsallianse? Her spriker litteraturen, og den redigerte boken til Blakkisrud og Rowe vil bidra til at leseren styrket kan utfolde seg i slike fagdebatter. Hovedbidraget til boka ligger i å studere spesifikke regionale forhold i Russlands østlige distrikt overfor Asia, og den skiller mellom ambisjoner og realiteter i russisk satsning. Bokas regionale russiske fokus gir et viktig bidrag til den etablerte engelskspråklige litteraturen på relasjonen mellom Russland og Kina som oftest fokuserer på mellomstatlige overordnede forhold. Nå skal det sies at boka, med sitt fokus på Russlands relasjon til Asia, favner bredere enn som så, men kapitlene reflekterer Moskvas Asia-politikk, hvor Kina er mest relevant.

Det viktige spørsmålet den redigerte boken søker å svare, er hvorvidt Ukrainakonflikten førte til et skifte i politikken overfor Kina og Asia, eller om senere års endring er et resultat av en videreført politikk fastsatt før 2014. Et hovedelement i boka er dermed å formidle i hvilken grad Ukraina-konflikten har formet Russlands utenrikspolitikk. Jeg mener dette er viktig fordi det indikerer noe om hvor permanent en tilnærming til Asia er for Moskva. Dersom Ukraina-konflikten er sterkt førende og har endret Russlands politikk overfor Kina, kan vi lettere se for oss en pendel tilbake mot Europa dersom Ukraina-konflikten skulle løses. Ved en lengre og gradvis strukturell overgang henimot Kina i russisk utenrikspolitikk er trenden trolig mer permanent. Dette gir føringer for et annet hovedelement i boken, nemlig hvordan Moskva nå forpakter det evige russiske dilemmaet - den utenrikspolitiske vektingen mellom en øst- og vestorientering. 
Redaktørene har fått bidragsyterne til å dra i samme retning henimot problemstillingen, og alle kapitlene diskuterer Ukraina-konfliktens innvirken. De fem første kapitlene og kapittel åtte har fokus på politikkutforming og -institusjoner og økonomiske eller sikkerhetspolitiske relasjoner til sine østlige nabostater. Kapittel seks om energisamarbeid og kapittel syv om Shanghai Cooperation Organisation (SCO) hever Russland-Kina-analysen opp til et mellomstatlig nivå, noe som er naturlig gitt at disse temaene ikke har en regional basis.

Blakkisrud og Rowe åpner i kapittel én med å betegne utfordringene i Russlands østlige distrikter, og identifiserer et rettidig gap i litteraturen etter Russlands annektering av Krim i 2014 og den påfølgende forverring av relasjonen til Vesten. Innledningen er god, kort og konsis på kapittelbidragene og bokas problemstilling. Kapittel to danner referansen for de senere kapitler når det gjelder russisk regional politikkutforming og institusjoner. Blakkisrud konkluderer med at Moskva fortsatt har en lang vei å gå før institusjonell reform gir ønsket økonomisk vekst og integrering med asiatisk økonomi, men at en sideeffekt kan bli en bedre integrering av Russlands østlige distrikt med resten av landet. Kapittel tre og fire tar for seg statlige økonomiske incentiv gjennom etableringen av forskjellige typer økonomiske soner. Begge finner at slik politikk så langt ikke har avkastet ønsket resultat. Trojakova peker på manglende koordinering mellom forskjellige myndighetsorganer, korrupsjon og dårlig investeringsklima. Min og Kang vektlegger problemet med å tiltrekke seg kapital til distriktet, det være seg nasjonalt eller internasjonalt, og at utsiktene ser dårlige ut.

Østevik og Kuhrt tar for seg sikkerhetspolitikk i kapittel fem, et stort og utfordrende tema de oppsummerer godt. Russisk sårbarhet langs et østlig distrikt i en demografisk og økonomisk limbo medfører at russisk Asia-politikk bremses av sikkerhetsbekymringer. Endringen i Russlands politikk var ikke først og fremst som følge av Ukraina-konflikten i 2014, men startet tidligere. Nå kan den relative størrelsen på styrkene langs Russlands østgrense diskuteres, samt hvordan Moskva vurderer trusselbildet i øst mellom Kina, Nord-Korea og USA/Japan. En mer spent situasjon på Russlands vestlige flanke og krigføringen i Syria kan nok også ha ført til en del omprioriteringer når det gjelder utplasseringer av styrker. Østenvik og Kuhrt fremstiller forøvrig en noe overdrevet betydning til det russisk-japanske militære samarbeidet, mens de underspiller det ekspanderende militære samarbeidet mellom Russland og Kina, spesielt på den maritime siden. Forfatterne kunne tatt en kort diskusjon om hvordan det kan ha seg at Moskva frykter Beijing, mens de samtidig leverer de siste avanserte våpensystemene som SU-35 og S-400. ${ }^{1}$

Kapittel seks tar for seg de viktige energiavtalene og samarbeidet mellom Russland og Kina, hvor Øverland og Kubajeva oppsummerer og redegjør godt for at det ikke er et markant skifte fra 2014, men at trenden innen olje og gass startet

\footnotetext{
${ }^{1}$ For informasjon om russiske våpenleveranser til Kina se rapporter og bøker publisert via Centre for Analysis of Strategies and Technologies (CAST): http://cast.ru/eng/.
} 
tidligere. De presiserer at energisamarbeidet ikke er rosenrødt og at kinesiske finansielle bidrag inn i russisk energisektor etter 2014 har vært moderat. Forfatterne mener at dette på én side viser at relasjonen har sine klare begrensninger. På en annen side vil internasjonale forhold kunne føre til økt samarbeid fremover. I kapittel syv tar Lanteigne for seg Kina-Russland-relasjonen i forhold til SCO. Lanteigne peker på den klassiske arbeidsdelingen mellom Moskva og Beijing i Sentral-Asia. Moskva har fokus på sikkerhet, mens Beijing vektlegger økonomi i SCO. Kinas voksende økonomi og tiltakende styrke gir en annen kurs enn Moskva når det gjelder regional og global sikkerhetspolitikk. Derfor konkluderer Lanteigne godt når han presiserer at en forsvarsallianse ikke er sannsynlig. I åttende kapittel finner Vakultsjuk at internasjonal handel med Russlands østlige distrikt er fallende etter 2014, men like fullt at Kina er et lyspunkt i så måte. Imidlertid kombineres Moskvas politikk med innenriks importsubstitutt dårlig med ønsket om økte internasjonale investeringer. Sanksjoner som følge av Ukraina-konflikten har dermed skapt komplikasjoner for Moskva i de østlige regionene, og derav Russlands orientering mot Asia.

Blakkisrud og Rowe oppsummerer med at Moskvas politikk for å utvikle sine østlige regioner og integrere disse inn henimot den asiatiske økonomien, så langt ikke har båret de tiltenkte gevinster. Ukraina-konflikten har gitt negative økonomiske konsekvenser også for Russlands østlige områder. Kapittelbidragene ser mer en fortsettelse av tidligere russisk politikk enn en markant endring som følge av Ukrainakonflikten i 2014. Likevel har det ført til en mer hastig Asia-politikk i Moskva, men de tidlige tegn gir ikke et optimistisk bilde av dens realisering. Oppsummert er dette en meget god bok som gir et oppdatert og realistisk bilde av Russlands østlige region og begrensningene i Moskvas viktige relasjon med Kina. Den er vel verdt lesingen. 